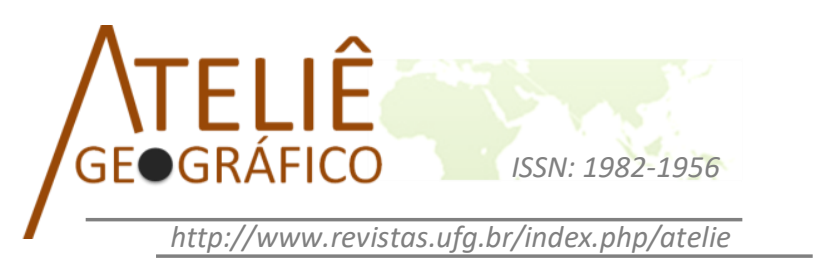

\title{
Receitas públicas tributárias e Regiões Produtivas Agrícolas: uma análise da Microrregião Sudoeste de Goiás (Goiás, Brasil)
}

\author{
Public tributary revenues and Productive Agricultural Regions: \\ an analysis of the Microregion Southwest of Goiás (state of \\ Goiás, Brazil)
}

\section{Ingresos tributarios públicos y Regiones Productivas Agrícolas: análisis de la Microrregión Sudoeste de Goiás (Estado de Goiás, Brasil)}

\author{
Bruno Carneiro Oliveira \\ Universidade Fedederal de Goiás \\ bcarneirodeoliveira@gmail.com
}

\begin{abstract}
Resumo
As receitas públicas tributárias possuem papel fundamental nas finanças dos municípios por conta de sua contribuição ao custeio local que é impactado de formas diferentes a depender do contexto espacial da região em que determinado município está inserido. Nesse sentido, o presente texto busca estabelecer uma análise e espacialização da dinâmica das receitas tributárias selecionadas IPTU, ITBI, ITR e ITR na Microrregião Sudoeste de Goiás enquanto uma Região Produtiva Agrícola nos anos de 2010 e 2015 por meio de revisão bibliográfica e análise de dados secundários. A análise demonstra que a produção agropecuária e os sentidos do agronegócio influenciam no uso e comercialização das terras, bem como na estrutura fundiária e disposição de equipamentos básicos de serviços públicos na Microrregião Sudoeste de Goiás.

Palavras-chave: Receita Pública Tributária; Região Produtiva Agrícola; Microrregião Sudoeste de Goiás; Regionalização.
\end{abstract}

\begin{abstract}
Public tributary revenues have a fundamental role in the finances of the municipalities due the contribution to the local defrayal which is impacted in several ways according the spatial context of the region certain municipality is inserted. Thus, this paper aims to establish an analysis and spatialization of the dynamics of the selected tributary revenues Urban Land and Territorial Tax (IPTU), Service Tax of Any Kind (ISSQN), Real Estate Transfer Tax (ITBI) and Tax on Rural Territorial Property (ITR) in the Microregion Southwest of Goiás (Goiás, Brazil) as a Productive Agricultural Region (RPA) in 2010
\end{abstract}


and 2015 through a bibliographic review and secondary data analysis. The analysis shows that the agricultural and cattle raising production and the senses of agribusiness influence on the use and commercialization of land, as well as on the land structure and disposition of basic equipments of public services in the Microregion Southwest of Goiás.

Keywords: Public tributary revenue; Productive Agricultural Region; Microregion Southwest of Goiás; Regionalization.

\section{Resumen}

Los ingresos tributarios públicos tienen un papel fundamental en las finanzas de los municipios debido a la contribución a la afluencia local que se ve afectada de varias maneras según el contexto espacial de la región que se inserta cierto municipio. Por lo tanto, este trabajo tiene como objetivo establecer un análisis y espacialización de la dinámica de los ingresos tributarios seleccionados Impuesto Territorial y Territorial (IPTU), Impuesto de Servicios de Cualquier Clase (ISSQN), Impuesto de Transmisiones Inmobiliarias (ITBI) e Impuesto a la Propiedad Territorial Rural (ITR) en el Microrregión Sudoeste de Goiás (Goiás, Brasil) como Región Agrícola Productiva (RPA) en 2010 y 2015 mediante una revisión bibliográfica y un análisis de datos secundarios. El análisis muestra que la producción agrícola y ganadera y los sentidos de la agroindustria influyen en el uso y comercialización de la tierra, así como en la estructura de la tierra y disposición de los equipos básicos de servicios públicos en la Microrregión Suroeste de Goiás.
\end{abstract}

Palabras clave: Ingresos Públicos Tributarios; Región Productiva Agrícola; Microrregión Sudoeste de Goiás; Regionalización.

\title{
Introdução
}

As receitas públicas tributárias, no âmbito das finanças públicas, são fundamentais para o custeio dos municípios brasileiros apesar da dificuldade de arrecadação pela maior parte deles. Quando se analisa o histórico tributário do Brasil por meio das Constituições, percebe-se que a Federal de 1988 foi a que mais descentralizou a arrecadação tributária e concedeu maior autonomia aos municípios nesse sentido. Entretanto, percebe-se que a "autonomia pela autonomia" nos municípios não é suficiente para os municípios, uma vez que a dependência de recursos oriundos das escalas estadual e federal, na maior parte dos casos, é decisiva para as despesas e investimentos locais.

Apesar disso, partimos da hipótese de que, mesmo com os regimentos tributários semelhantes, a arrecadação tributária pode se dar de forma diferenciada a depender das regiões. No presente trabalho buscamos discutir como isso ocorre a partir da análise das receitas públicas tributárias Imposto Predial Territorial Urbano, Imposto Sobre Transmissão de Bens Imóveis e Imposto Territorial Rural na Microrregião Sudoeste de Goiás (MSG), Goiás, Brasil, região historicamente marcada pela produção agropecuária e pelas dinâmicas promovidas pelo agronegócio, e incentivada no âmbito das ações do Estado para seu crescimento.

Os passos metodológicos foram uma revisão bibliográfica sobre os temas finanças públicas, com ênfase nas receitas tributárias selecionadas, e sobre os aspectos sociais, demográficos e econômicos da MSG. A partir dos dados secundários coletados 
nas bases de dados do Instituto Brasileiro de Geografia e Estatística, Instituto Mauro Borges e Tribunal de Contas dos Municípios do Estado de Goiás realizamos a elaboração de mapas, gráficos, tabelas e quadros que demonstrar os resultados da pesquisa com recorte temporal para os anos de 2010 e 2015. Buscamos contribuir com um diagnóstico sobre a dinâmica tributária dos municípios para que haja uma reflexão da função das receitas públicas enquanto instrumentos decisivos para o custeio local.

A composição tributária vigente é resultado da reforma tributária aliada à Constituição Federal de 1988 (CF 1988), que possibilitaram retomar os princípios de descentralização tributária e fiscal, como é possível observar no Quadro 01. De modo análogo aos princípios de autonomia dessa Constituição em diferentes âmbitos, seu artigo 145 estabelece que os tributos (impostos, taxas e contribuições de melhoria) poderão ser instituídos pelos estados e municípios. Além disso, ocorre uma maior divisão do total arrecadado pela União, havendo fundos e transferências constitucionais para os estados e municípios. Nosso estudo direciona-se a uma composição mais detalhada da composição tributária municipal baseada na CF 1988, com destaque para suas funções e cálculos de alíquota no exemplo de alguns municípios do presente estudo.

O custeio do poder executivo municipal estabelecido a partir do Sistema Tributário Nacional (BRASIL, 1966) é formado pelas receitas tributárias de origem municipal, transferências constitucionais e pelos fundos, que foram incluídos por conta de sua representatividade nas finanças municipais. O Quadro 01 demonstra essa composição.

Quadro 01: Origem das receitas do executivo municipal.

\begin{tabular}{|c|c|c|}
\hline \multirow{5}{*}{ Transferências constitucionais } & \multirow{3}{*}{ Federais } & FPM (Fundo de Participacão dos Municípios) \\
\hline & & $\begin{array}{l}\text { CIDE (Contribuição de Intervenção no Domínio } \\
\text { Econômico) }\end{array}$ \\
\hline & & ITR $^{1}$ (Imposto sobre Propriedade Territorial Rural) \\
\hline & \multirow{2}{*}{ Estaduais } & $\begin{array}{c}\text { ICMS (Imposto sobre Circulação de Mercadorias e } \\
\text { Serviços) }\end{array}$ \\
\hline & & $\begin{array}{c}\text { IPVA (Imposto sobre Propriedade de Veículos } \\
\text { Automotivos) }\end{array}$ \\
\hline \multirow{3}{*}{$\begin{array}{l}\text { Receitas tributárias } \\
\text { municipais }\end{array}$} & \multicolumn{2}{|c|}{ IPTU (Imposto sobre Propriedade Predial Territorial Urbana) } \\
\hline & \multicolumn{2}{|c|}{ ITBI (Imposto sobre Transmissão de Bens Imóveis) } \\
\hline & \multicolumn{2}{|c|}{ ISSQN (Imposto sobre Serviços de Qualquer Natureza) } \\
\hline \multirow{2}{*}{ Fundos } & \multicolumn{2}{|c|}{ FUNDEB (Fundo Nacional de Desenvolvimento da Educação Básica) } \\
\hline & \multicolumn{2}{|c|}{$\begin{array}{l}\text { FMS (Fundo Municipal de Saúde) } \\
\end{array}$} \\
\hline
\end{tabular}

Fonte: Arrais (2014).

\footnotetext{
${ }^{1}$ Caso haja pactuação de convênio com o governo federal, o município recebe $100 \%$ da arrecadação de ITR.
} 
Outras fontes das receitas municipais são as taxas e as contribuições de melhoria, que variam entre os municípios para fins de regulação e manutenção de determinado uso público. As taxas geralmente obedecem a diferentes critérios, que variam conforme a localização por zonas para fins de definição das alíquotas. A competência das receitas tributárias municipais decorre, principalmente, da cobrança de impostos derivados da transmissão de bens imóveis, da propriedade predial e territorial de determinado imóvel urbano, da prestação de serviços de qualquer natureza, além de outros estabelecidos pelo município.

Coloca-se como necessário verificar como o uso do solo e a concentração de serviços se apresentam como fatores responsáveis pelo atendimento das demandas em relação à implantação, regulação e manutenção da infraestrutura e dos equipamentos de uso coletivo dos municípios. É desse modo que a receitas tributárias IPTU, ITBI, ISSQN e ITR ganham relevância, uma vez que estão intrinsecamente ligadas à dinâmica fundiária, econômica e de custeio dos municípios, sendo por isso as receitas tributárias selecionadas como objeto de estudo do presente trabalho. Consideramos inserir o ITR no presente estudo por acreditarmos que a partir do estabelecimento de convênio entre governo federal e município, a transferência constitucional federal passa a ser uma receita de origem municipal, além de apresentar características ligadas à dinâmica fundiária dos municípios analisados. Adiante, será analisado como as receitas selecionadas se espacializam e sua relação com a dinâmica socioespacial dos municípios da Microrregião Sudoeste de Goiás.

\section{Caracterização da Microrregião Sudoeste de Goiás (MSG)}

As regionalizações enquanto fato $^{2}$ e enquanto ferramenta propostas por Ribeiro (2004) possuem caráter ideológico e vinculado a recursos administrativos, porém a última possui o Estado enquanto protagonista visível no âmbito do planejamento. Concordamos com Haesbaert (2014) quando argumenta que a regionalização deve ser considerada um ato de poder, afirmativa essa que pode ser justificada por Ribeiro (2004, p. 200) quando afirma que "o ato regionalizador compreende a institucionalização de fronteiras e limites, com vistas a implementação de uma determinada ação". Nesse sentido, o ato relaciona-se a definição de cenário, contexto e escala em que as metas da ação estão almejadas ou consolidadas no âmbito analítico, político, econômico ou social.

Sendo regionalizar um ato de poder, supõe-se que as relações de poder sejam assimétricas e permitem condições para que atores econômicos hegemônicos se apropriem da região como ferramenta. A Microrregião Sudoeste de Goiás (MSG),

\footnotetext{
${ }^{2} \mathrm{~A}$ regionalização como fato vincula-se às formas de se pensar integradamente a "estrutura espacial, a dinâmica socioeconômica e político-jurídica da formação social brasileira" (RIBEIRO, 2004, p. 195). Para a autora, esta é uma regionalização ligada às disputas de poder inseridas nas variadas maneiras de apropriação do território.
} 
nesse contexto, é regionalizada para fins estatísticos pelo Estado brasileiro, por meio do Instituto Brasileiro de Geografia e Estatística (IBGE), para atender diferentes prerrogativas do Estado. É, portanto, uma região criada e usada enquanto ferramenta para a condução de um projeto específico.

A MSG pode estar inserida no que Elias (2011) conceitua como Região Produtiva Agrícola (RPA). A RPA configura-se como região formada por lugares funcionais de circuitos espaciais da produção formados por cooperações para a produção de commodities, que contribuem para manter o agronegócio globalizado. Para a autora, nessas regiões o processo de urbanização tem sido catalisado pela difusão do agronegócio, havendo uma clara inter-relação entre o campo e a cidade, atividades agrícolas e agroindustriais que ocorrem de forma científica e global, moldadas inicialmente pela modernização, e que tem contribuído para o crescimento demográfico e econômico regional.

Para Elias (2011), as RPAs são regiões comandadas pelo agronegócio com a função de produzir commodities para exportação dentro de um sistema econômico capitalista caracterizado pela união da indústria, agricultura, cidade e campo no processo produtivo, que foi capturado pelas multinacionais do setor agropecuário. Para Delgado (2012, p. 94), o agronegócio constitui "uma associação do grande capital agroindustrial com a grande propriedade fundiária. Essa associação realiza uma estratégia econômica de capital financeiro, perseguindo o lucro e a renda da terra, sob patrocínio de políticas do Estado". Nesse sentido, o agronegócio pode ser identificado como a industrialização da agricultura por meio do incentivo do Estado, seja por meio de isenções fiscais ou oferta de crédito.

A agricultura comercial no sudoeste de Goiás inicia-se a partir da década de 1960 e consolida-se na década de 1970, com a oferta de aparato técnico, econômico e logístico provenientes do incentivo público, conforme argumentam Ferreira e Fernandes Filho (2003). O aparato econômico proporcionado pela oferta de crédito agrícola subsidiou o aparato técnico, que possibilitou a compra e aplicação de insumos para o crescimento da produção agrícola em larga escala. Por fim, com a construção de eixos viários, a exemplo da BR-060 e BR-364, a MSG torna-se uma região agrícola produtiva com infraestrutura para o escoamento de sua produção.

No tangente aos aspectos econômicos, a MSG foi a segunda microrregião de maior arrecadação de Produto Interno Bruto no estado de Goiás em 2013. Nesse ano, os maiores destaques em sua composição foram os setores agropecuário e industrial. A agropecuária participou com $26,97 \%$ do PIB do setor em Goiás, liderando esse quesito no estado. Já a indústria participou com 10,26\% do PIB, sendo a terceira microrregião que mais arrecadou no ano em Goiás, nesse setor (IMB, 2013). São alguns dos reflexos do agronegócio impulsionado pela intervenção do Estado com programas de incentivo a modernização da agricultura e a instalação de empresas de capital nacional e estrangeiro. 
Reflexos desses investimentos e que tanto tem favorecido o setor do agronegócio na região são os percentuais de representatividade expressos na Tabela 01. A região é líder na produção de sorgo e soja e é a segunda maior produtora de cana-deaçúcar (perdendo apenas para Microrregião Meia Ponte, com 24,75\% da produção total de Goiás, em 2015). No âmbito da pecuária, a microrregião destaca-se como líder na produção bovina, suína e de aves. São pontos decisivos para a compreensão do crescimento do agronegócio na MSG.

Tabela 01: Produção agropecuária em Goiás e Microrregião Sudoeste de Goiás (2000, 2010, 2015).

\begin{tabular}{|c|c|c|c|c|c|c|}
\hline \multirow{2}{*}{$\begin{array}{l}\text { Tipo de produção } \\
\text { agropecuária }\end{array}$} & \multicolumn{2}{|c|}{2000} & \multicolumn{2}{|c|}{2010} & \multicolumn{2}{|c|}{2015} \\
\hline & Goiás & $\begin{array}{l}\text { (\%) MSG } \\
\text { em Goiás }\end{array}$ & Goiás & $\begin{array}{l}\text { (\%) MSG } \\
\text { em Goiás }\end{array}$ & Goiás & $\begin{array}{l}\text { (\%) MSG } \\
\text { em Goiás }\end{array}$ \\
\hline Aves (cabeças) & 26.444 .415 & $25,19 \%$ & 55.156 .362 & $34,28 \%$ & 64.604 .285 & $32,68 \%$ \\
\hline Bovinos (cabeças) & 18.399 .222 & $14,12 \%$ & 21.347 .881 & $12,08 \%$ & 21.887 .720 & $11,30 \%$ \\
\hline Suínos (cabeças) & 1.174 .360 & $21,33 \%$ & 2.046 .727 & $47,31 \%$ & 2.033 .914 & $52,77 \%$ \\
\hline $\begin{array}{l}\text { Cana-de-açúcar - } \\
\text { Área Colhida } \\
\text { (hectares) }\end{array}$ & 139.186 & $22,06 \%$ & 578.666 & $26,79 \%$ & 911.847 & $22,82 \%$ \\
\hline $\begin{array}{l}\text { Soja - Área Colhida } \\
\text { (hectares) }\end{array}$ & 1.491 .066 & $49,92 \%$ & 2.445 .600 & $41,76 \%$ & 3.260 .025 & $37,50 \%$ \\
\hline $\begin{array}{c}\text { Sorgo - Área } \\
\text { Colhida (hectares) }\end{array}$ & 175.850 & $69,05 \%$ & 245.308 & $50,83 \%$ & 243.974 & $26,72 \%$ \\
\hline
\end{tabular}

Fonte: IBGE (2000, 2010, 2015).

As RPAs possuem a característica de serem polarizadas por determinado centro dotado de infraestrutura, concentração de serviços e que respondem pela gestão e regulação da economia do agronegócio. Elias (2006) conceituou esses centros como cidades do agronegócio. Para a autora, vários municípios brasileiros devem sua consolidação e influência regional à expansão do agronegócio, e junto a municípios próximos puderam desenvolver uma rede de demandas produtivas. As concessões de crédito, tanto do setor público quanto do privado, contribuíram para o crescimento do agronegócio nesses centros. Na MSG, esse fator tem impactado nas condições atuais da estrutura fundiária da região.

É o caso do município de Rio Verde, que se consolida como polo regional na MSG exercendo centralidade entre os municípios por meio da maior parte da oferta de equipamentos de serviços na região. Diferentemente do caso de Goiânia enquanto polo na Região Metropolitana de Goiânia, por exemplo, nos últimos 15 anos Rio Verde tem continuado a atrair populações tanto de municípios próximos quanto de outros estados, reafirmando sua condição enquanto polo regional. Santos e Silveira (2008) afirmam que uma das causas para municípios como Rio Verde para isso pode-se dever ao aumento do número de agricultores que residem na cidade, que apresenta funcionalidade por ser local de regulação do campo e centro de comando de empresas multinacionais. 
A produção agrícola de milho e soja e a capacidade industrial instalada para processá-los aliadas à existência de frigoríficos de carne bovina atraíram empresas como a Perdigão (BRF) - especializada em aves e suínos -, que anunciou sua implantação em 1996 e iniciou os abates em 2000, como é possível verificar em Borges (2006). Com isso, houve a elaboração do complexo agroindustrial de carne que atualmente é um dos principais responsáveis pelo superávit da balança comercial de Rio Verde. No ano de 2015, por exemplo, o município foi, pelo segundo ano consecutivo, o maior exportador do estado de Goiás ${ }^{3}$.

Como o agronegócio é caracterizado, de um lado, pela atuação da indústria, por meio da produção de sementes e defensivos agrícolas, e de outro, com a industrialização dos produtos extraídos do campo, a centralidade de Rio Verde estendese desde a concentração de pesquisas, produção e venda de novas sementes até a industrialização e comércio das mercadorias extraídas do campo. Nota-se, ainda, a implantação de infraestrutura logística, como o exemplo da Ferrovia Norte-Sul que, conforme mencionado por Campos (2015), passa pelos municípios de Rio Verde e Santa Helena e possui pátios multimodais em construção com aparato técnico que podem possibilitar a futura formação de polos industriais.

O Programa de Desenvolvimento dos Cerrados (Polocentro), que possuía em Rio Verde um de seus polos de atuação, é um exemplo de ação apoiado pelo Estado que incentivou a conversão de uso da terra de pecuária extensiva e alimentos básicos para a crescente substituição pelas monoculturas como arroz, milho e soja. Nesse período de crescimento da produção das monoculturas, é possível perceber aumento da população urbana de Rio Verde de 64,86\%, entre 2000 e 2010. Caso semelhante ocorre em Jataí e Mineiros, que crescem 84,95\% e 71,78\%, respectivamente, percentuais que denotam a inter-relação entre campo e cidade ocasionada pela dinâmica agroindustrial: se no campo tem-se a produção de commodities, criação e abate intensivo de bovinos e aves, por exemplo, na cidade ocorre o apoio no âmbito técnico, informacional e financeiro, com a presença de equipamentos de serviços essenciais para a manutenção do agronegócio. Esses fatores consequentemente impactam na dinamicidade da economia urbana dos municípios, como pode ser conferido na evolução populacional rural e urbana e de produção de commodities ilustrado na Tabela 02 .

Essa dinâmica, no entanto, tende a substituir as produções para o mercado interno e prioriza a produção para o mercado externo. É o caso do arroz que, com exceção de Aparecida do Rio Doce e Palestina de Goiás, teve queda de produção entre 2000 e 2010 em praticamente toda a microrregião. Diferentemente, a produção de cana-de-açúcar e de soja aumenta em 2010, inclusive em municípios que não tinham esse tipo de produção, atraídos por usinas, agroindústrias e pela intervenção de crédito público que influenciam nos novos tipos de plantio. Essas modalidades impactam

3 Disponível em: <http://www.goiasagora.go.gov.br/rio-verde-lidera-ranking-de-municipios-que-maisexportaram-em-2015/>. Acesso em: 03 de setembro de 2016. 
diretamente nos usos de solo e preço da terra na microrregião, além de impactos ambientais de diferentes ordens ocasionados pelo uso intensivo do solo na produção agrícola.

Tabela 02: População rural e urbana e produção agrícola de cana-de-açúcar, arroz e soja $(2000,2010)$.

\begin{tabular}{|c|c|c|c|c|c|c|c|c|c|c|}
\hline & \multirow{2}{*}{\multicolumn{2}{|c|}{$\begin{array}{c}\text { Pop. Rural } \\
\text { (habitantes) }\end{array}$}} & \multirow{2}{*}{\multicolumn{2}{|c|}{$\begin{array}{c}\text { Pop. Urbana } \\
\text { (habitantes) }\end{array}$}} & \multicolumn{6}{|c|}{ Área Colhida (ha) } \\
\hline & & & & & \multicolumn{2}{|c|}{ Cana-de-açúcar } & \multicolumn{2}{|c|}{ Soja } & \multicolumn{2}{|c|}{ Arroz } \\
\hline & 2000 & 2010 & 2000 & 2010 & 2000 & 2010 & 2000 & 2010 & 2000 & 2010 \\
\hline Aparecida do Rio Doce & 595 & 477 & 1.807 & 1.950 & - & 558 & - & 500 & 94 & 300 \\
\hline Aporé & 1.331 & 1.262 & 2.096 & 2.541 & - & 3.668 & 501 & 1.800 & 200 & - \\
\hline Caiapônia & 3.854 & 4.488 & 10.819 & 12.269 & 18 & 70 & 38.000 & 48.000 & 8.000 & 2.600 \\
\hline Castelândia & 391 & 294 & 3.491 & 3.344 & 2.440 & 3.350 & 3.000 & 7.000 & 100 & 40 \\
\hline Chapadão do Céu & 960 & 1.123 & 2.818 & 5.878 & - & 21.035 & 67.425 & 110.000 & 7.746 & 700 \\
\hline Doverlândia & 3.229 & 2.976 & 5.329 & 4.916 & 15 & 660 & 592 & 8.500 & 3.000 & 1.800 \\
\hline Jataí & 6.630 & 6.996 & 68.821 & 81.010 & 60 & 18.000 & 157.300 & 210.000 & 4.500 & 200 \\
\hline Maurilândia & 532 & 401 & 8.437 & 11.120 & 7.980 & 10.440 & 3.500 & 5.000 & 50 & 30 \\
\hline Mineiros & 4.364 & 4.649 & 34.660 & 48.286 & 15 & 22.260 & 100.000 & 105.000 & 3.500 & 2.000 \\
\hline Montividiu & 2.326 & 1.988 & 5.410 & 8.584 & - & 11.500 & 70.000 & 101.000 & 1.500 & 350 \\
\hline Palestina de Goiás & 1.487 & 1.191 & 1.820 & 2.180 & - & - & - & 4.000 & 650 & 800 \\
\hline Perolândia & 1.091 & 1.091 & 1.700 & 1.859 & - & 2.165 & 52.000 & 50.000 & 2.000 & 500 \\
\hline Portelândia & 879 & 729 & 2.817 & 3.110 & & 850 & 20.000 & 22.000 & 300 & 400 \\
\hline Rio Verde & 10.473 & 12.884 & 106.079 & 163.540 & 4.000 & 10.500 & 175.000 & 265.000 & 3.000 & 1.000 \\
\hline Santa Helena de Goiás & 2.196 & 1.654 & 32.349 & 34.815 & 15.762 & 35.640 & 35.000 & 44.000 & - & - \\
\hline Santa Rita do Araguaia & 459 & 765 & 4.628 & 6.159 & 6 & - & 310 & 3.500 & 500 & 400 \\
\hline Santo Antônio da Barra & 761 & 1.051 & 3.291 & 3.372 & 410 & 3.540 & 3.000 & 5.000 & 50 & 50 \\
\hline Serranópolis & 2.352 & 1.947 & 4.095 & 5.534 & - & 10.771 & 18.700 & 31.000 & 1.500 & 200 \\
\hline
\end{tabular}

Fonte: IBGE $(2001,2011)$.

A localização das usinas de cana-de-açúcar da MSG pode ser visualizada na Figura 01, com base nos dados da União da Indústria de Cana-de-Açúcar (UNICA) (2016). Diferentes grupos nos ramos do açúcar e álcool têm instalado usinas nos municípios da MSG atraídos pela dinamicidade, recursos e incentivos que a microrregião oferece. Destacamos a Odebrecht Agroindustrial, com duas unidades na microrregião (Perolândia e Mineiros) e que possui outras sete unidades no Brasil. A 
Odebrecht figura-se como um dos maiores conglomerados de empresas de diferentes ramos no Brasil.

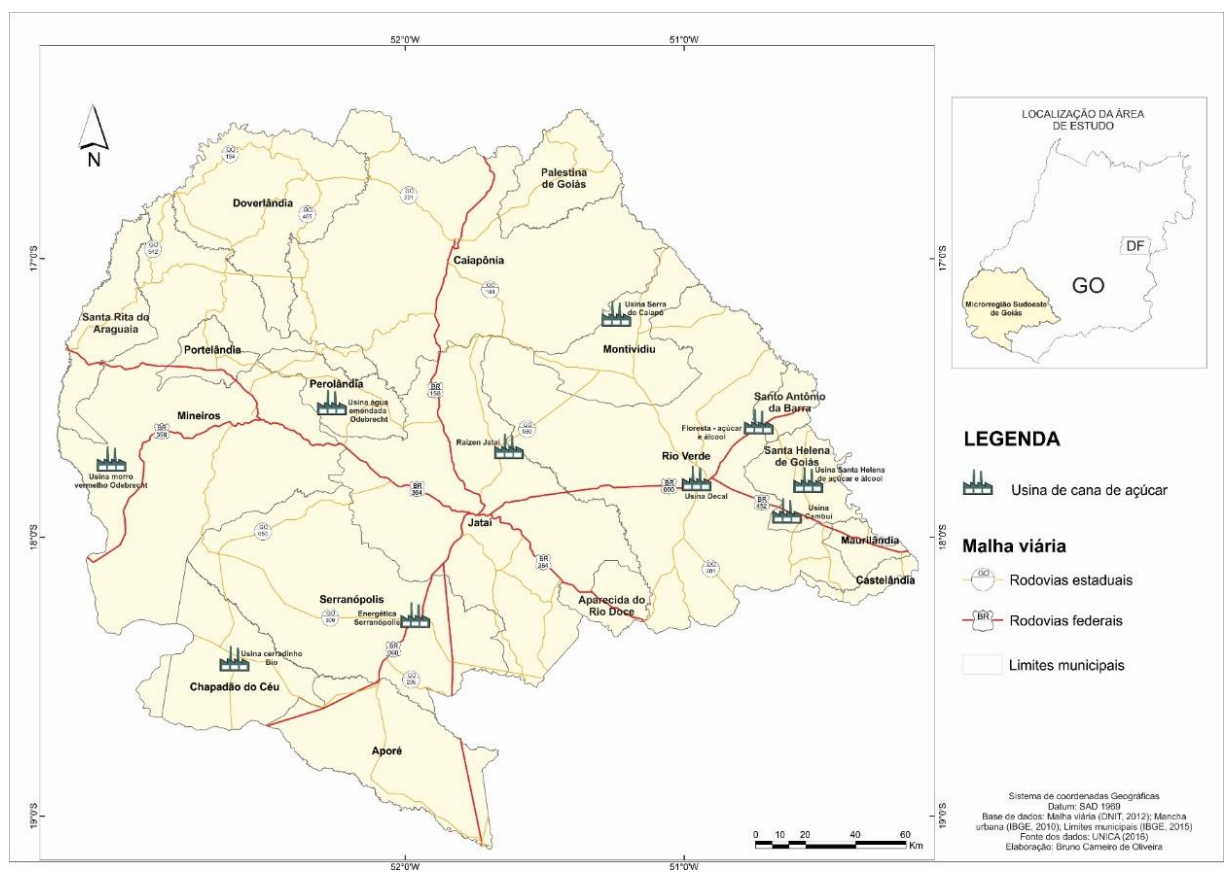

Figura 01: Espacialização de usinas de cana-de-açúcar na MSG. Fonte: UNICA (2016).

A presença do grupo exemplifica as razões de atração das corporações para a MSG: a região apresenta boa logística, baseando-se nos eixos rodoviários presentes, solo produtivo obtido por meio de correção, topografia e clima adequados que possibilitam o investimento no cultivo da cana-de-açúcar e nas agroindústrias de açúcar e álcool. Além disso, o impacto de programas de incentivo do estado de Goiás como o Produzir, sucessor do Fomentar, representam impacto considerável na microrregião. Conforme Borges (2014), entre os anos de 2001 e 2012 a MSG obteve o quarto maior número de projetos aprovados, o que possibilitou o maior montante de investimento industrial entre as microrregiões de Goiás (23,3\% do total). 
Tabela 03: Variação da taxa de crescimento geométrico populacional na MSG em \%.

\begin{tabular}{|c|c|c|c|}
\hline \multirow{2}{*}{ MUNICÍPIO } & \multicolumn{3}{|c|}{ PERÍODOS } \\
\hline & $2000-2010$ & 2010-2015 & $2000-2015$ \\
\hline Aparecida do Rio Doce & 0,1 & 0,34 & 0,44 \\
\hline Aporé & 1,05 & 0,7 & 1,75 \\
\hline Caiapônia & 1,34 & 0,8 & 2,15 \\
\hline Castelândia & 0,65 & 0,01 & $-0,64$ \\
\hline Chapadão do Céu & $-6,36$ & 2,07 & 8,56 \\
\hline Doverlândia & $-0,81$ & $-0,06$ & $-0,87$ \\
\hline Jataí & 1,55 & 0,87 & 2,44 \\
\hline Maurilândia & 2,54 & 1,18 & 3,75 \\
\hline Mineiros & 3,1 & 1,34 & 4,48 \\
\hline Montividiu & 3,17 & 1,36 & 4,58 \\
\hline Palestina de Goiás & 0,19 & 0,37 & 0,57 \\
\hline Perolândia & 0,56 & 0,51 & 1,07 \\
\hline Portelândia & 0,38 & 0,45 & 0,83 \\
\hline Rio Verde & 4,23 & 1,63 & 5,93 \\
\hline Santa Helena de Goiás & 0,54 & 0,51 & 1,06 \\
\hline Santa Rita do Araguaia & 3,13 & 1,35 & 4,52 \\
\hline Santo Antônio da Barra & 0,88 & 0,64 & 1,52 \\
\hline Serranópolis & 1,5 & 0,85 & 2,36 \\
\hline MSG & 0,98 & 0,82 & 2,47 \\
\hline
\end{tabular}

Fonte: IBGE $(2001,2011,2015)$. Elaboração: Bruno Carneiro de Oliveira.

No que se refere à demografia, a MSG no ano 2000 possuía um total de 344.377 habitantes, passando para o total de 446.433 habitantes em 2010. As estimativas populacionais indicaram que a microrregião havia passado de meio milhão de habitantes no ano de 2015, crescendo no período de quinze anos $46,17 \%$, a uma taxa de crescimento geométrico de 3,51. As maiores taxas de crescimento geométrico populacional (Tabela 03) foram para os municípios de Rio Verde, Montividiu e Mineiros. As relações dessas taxas com os municípios podem estar ligadas à instalação de empresas atraídas por incentivos públicos, o que pode ter ocasionado a migração populacional de outros estados para tais localidades. Com relação à origem da população da MSG, $18 \%$ da população da MSG, no ano 2000, era oriunda de outras regiões brasileiras, percentual que aumentou para 20,5\% em 2010. Para as populações dessas regiões brasileiras, a MSG pode ser atrativa pelas ofertas de emprego nas agroindústrias, tanto no âmbito da mão-de-obra barata sem qualificação quanto para a especializada.

\section{A dinâmica das receitas tributárias selecionadas na MSG}

Percebemos que a MSG possui características notadamente marcadas pela produção agropecuária e pelas corporações no âmbito do agronegócio que impactam na dinâmica socioespacial dos municípios da MSG. Mesmo que os Códigos Tributários normatizem praticamente as mesmas formas para que o município arrecade recursos, o contexto espacial da microrregião impacta diferencialmente na arrecadação de receitas 
públicas tributárias quando comparado a municípios circunscritos em ambientes metropolitanos que possuem uma dinâmica integrada e mediada por fatores como o transporte coletivo metropolitano, como analisamos em trabalho anterior (OLIVEIRA, 2015).

Nesse sentido, a presente análise parte da arrecadação de recursos provenientes de receitas públicas tributárias selecionadas para os municípios da MSG. Cada receita está ligada a aspectos fundamentais da dinâmica espacial dessas regiões. Os impostos territorial e predial urbano, de transmissão de bens imóveis e territorial rural estão ligados às formas de ocupação e uso do solo e respectiva dinâmica de comercialização, enquanto os impostos sobre serviços relacionam-se à inferência da disponibilidade de serviços e equipamentos de uso coletivo dos municípios em estudo.

Tabela 04: Número e crescimento percentual de domicílios na RMG e MSG entre 2000 e 2010.

\begin{tabular}{cccc}
\hline MSG & $\mathbf{2 0 0 0}$ & $\mathbf{2 0 1 0}$ & Crescimento (\%) \\
\hline Aparecida do Rio Doce & 703 & 818 & 16,36 \\
\hline Aporé & 1.027 & 1.262 & 22,88 \\
\hline Caiapônia & 4.273 & 5.676 & 32,83 \\
\hline Castelândia & 1.083 & 1.203 & 11,08 \\
\hline Chapadão do Céu & 1.026 & 2.096 & 104,29 \\
\hline Doverlândia & 2.395 & 2.608 & 8,89 \\
\hline Jataí & 21.395 & 27.661 & 29,29 \\
\hline Maurilândia & 2.592 & 3.554 & 37,11 \\
\hline Mineiros & 10.642 & 15.933 & 49,72 \\
\hline Montividiu & 2.140 & 3.286 & 53,55 \\
\hline Palestina de Goiás & 983 & 1.114 & 13,33 \\
\hline Perolândia & 638 & 929 & 45,61 \\
\hline Portelândia & 1.036 & 1.236 & 19,31 \\
\hline Rio Verde & 32.769 & 55.487 & 69,33 \\
\hline Santa Helena de Goiás & 9.891 & 11.871 & 20,02 \\
\hline Santa Rita do Araguaia & 1.505 & 2.260 & 50,17 \\
\hline Santo Antônio da Barra & 1.112 & 1.434 & 28,96 \\
\hline Serranópolis & 1.959 & 2.423 & 23,69 \\
\hline Microrregião Sudoeste de Goiás & $\mathbf{9 7 . 1 6 9}$ & $\mathbf{1 4 0 . 8 5 1}$ & $\mathbf{4 4 , 9 5}$ \\
\hline
\end{tabular}

Fonte: IBGE (2000; 2010). Elaboração: Bruno Carneiro de Oliveira.

Os municípios de Chapadão do Céu, Rio Verde e Montividiu obtiveram crescimento domiciliar de 104,29\%, 69,33\% e 53,55\%, respectivamente, que está 
ligado a fatores relacionados ao crescimento da agricultura moderna na região, o que impacta diretamente na atração e implantação de agroindústrias e da expansão da agricultura mecanizada. Em Chapadão do Céu, por exemplo, não havia a produção de cana-de-açúcar no ano 2000, porém, em 2010 o município passa a ser o terceiro maior produtor da commoditie na MSG (Tabela 04), processo catalisado pela implantação de empresas como a Usina Porto das Águas. É ainda o segundo maior produtor de soja da MSG, com área colhida de 110.000 hectares, atrás apenas de Rio Verde, com 265.000 ha (IBGE, 2010). Esses fatores impulsionaram o crescimento populacional (no ano 2000: 3.778 habitantes; em 2010: 7.001 habitantes) e domiciliar do município através de populações externas atraídas por novas oportunidades em um município em crescimento.

O Imposto Predial Territorial Urbano (IPTU) figura-se como um imposto que incide sobre a posse de uma propriedade predial e territorial de um imóvel que esteja localizado na zona urbana do município. Contribuinte é o proprietário ou dominador útil do imóvel. A base de cálculo do IPTU é o valor venal do imóvel, ou seja, é basicamente o valor estimado de determinado imóvel no mercado pelo poder público. Sua alíquota varia entre os municípios e regimentos nos códigos tributários. O IPTU é um imposto regulador do espaço urbano, pois pode contribuir para a homogeneidade socioespacial e controle da especulação imobiliária nas cidades. É concebido como um dos elementos responsáveis pelo financiamento de políticas urbanas, sendo importante para a implantação e manutenção da infraestrutura urbana.

A dinâmica do IPTU na MSG possui influência dos impactos no uso e ocupação do solo ocasionado pela agricultura moderna e pelo agronegócio que impactam diretamente no padrão de uso do solo, como pode ser conferido em Arrais (2002). Ao invés dos estoques de terra rurais terem destino imobiliário, como ocorre nas regiões metropolitanas, nas RPAs a terra possui valor agregado pela produtividade esperada pelos atores do agronegócio (agricultores, corporações agroindustriais, Estado etc.). Isso proporciona baixo impacto na arrecadação de IPTU nos municípios da microrregião. Os requisitos de cobrança do IPTU - que tem como base de cálculo o valor venal do imóvel concebido a partir do provável preço de mercado - variam conforme o Código Tributário de cada município, como pode ser visualizado no Quadro 02.

No ano de 2010, Rio Verde possuía 56,01\% do total arrecadado, seguido por Jataí e Mineiros, com 25,83\% e 11,90\%, respectivamente. Em 2015, a concentração de arrecadação de IPTU em Rio Verde diminuiu para 48,9\%, enquanto a arrecadação de Jataí e Mineiros aumentaram e representaram $28,67 \%$ e $12,12 \%$ do total. Na relação per capita, a média de arrecadação de IPTU da MSG em 2010 e 2015 foi de R\$ 45,62/hab. e R \$ 86,73/hab. As menores relações de arrecadação por habitante em 2010 ocorreram nos municípios de Maurilândia (R \$ 2,42/hab.), Santo Antônio da Barra (R \$ 3,28/hab.) e Castelândia ( $\mathrm{R} \$ 4,92 / \mathrm{hab}$.), enquanto as maiores ocorreram em Rio Verde 
( $\mathrm{R} \$$ 64,65), Jataí (R \$ 59,77/hab.) e Mineiros (R \$ 45,78/hab.). Em 2015, Santo Antônio da Barra (R\$ 0,76/hab.), Palestina de Goiás ( $\mathrm{R}$ \$ 7,30/hab.) e Doverlândia ( $\mathrm{R}$ \$ $11,00 /$ hab.) registraram as menores relações per capita, enquanto Serranópolis (R\$ 156,26/hab.), Jataí (R\$ 130,39/hab.) e Chapadão do Céu (R\$ 129,64/hab.) foram os maiores municípios nesse aspecto.

Quadro 02: Requisitos para cobrança e arrecadação de IPTU em municípios selecionados da MSG.

\begin{tabular}{|c|l|}
\hline Município & \multicolumn{1}{c|}{ Critérios para a cobrança } \\
\hline \multirow{3}{*}{ Rio Verde, Jataí, Montividiu } & $\begin{array}{l}\text { Pelo menos 2 (dois) dos melhoramentos seguintes: I - meio-fio ou } \\
\text { calçamento, com canalização de águas pluviais; II - abastecimento } \\
\text { de água; III - sistema de esgotos sanitários; IV - rede de iluminação } \\
\text { pública, com ou sem posteamento para distribuição domiciliar; V - } \\
\text { escola primária ou posto de saúde a uma distância máxima de três } \\
\text { quilômetros do imóvel considerado. }\end{array}$ \\
\hline \multirow{2}{*}{ Aparecida do Rio Doce } & $\begin{array}{l}\text { Os terrenos arruados ou não, sem edificação ou em que houver } \\
\text { edificação interditada, paralizada, condenada, em ruínas ou em } \\
\text { demolição. }\end{array}$ \\
\hline
\end{tabular}

Fonte: Códigos Tributários dos municípios selecionados. Coleta e elaboração: Bruno Carneiro de Oliveira.

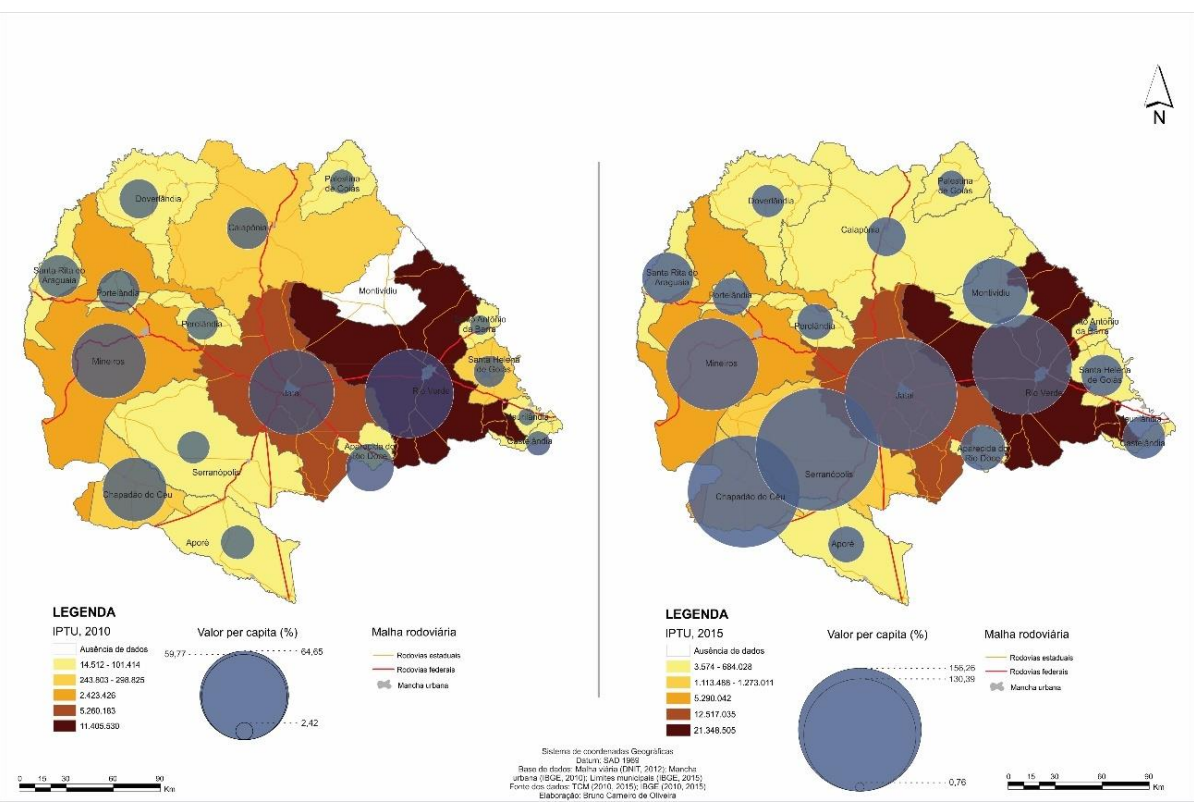

Figura 02: Espacialização do IPTU na RMG em 2010 e 2015.

Fonte: TCM (2010, 2015); IBGE (2010, 2015). 
A relação entre infraestrutura e arrecadação de IPTU, quando analisada junto aos critérios de cobrança do imposto, torna-se clara ao notar-se que nos anos de 2010 e 2014 Santo Antônio da Barra não possuía infraestrutura de esgoto, enquanto Jataí, em 2010, tinha 55,8\% da população atendida por rede de esgoto, percentual que aumentou para 68,2\% em 2014 (IBGE, 2010; 2014). Na MSG existem municípios em que o IPTU apresenta pouca representatividade no orçamento, como mostrado nas relações per capita, o que está ligado a outros fatores, além de formas mais severas de cobrança do tributo e de infraestrutura.

O Imposto Sobre Transmissão de Bens Imóveis (ITBI) configura-se por tributar a transferência de bens imóveis, seja por domínio útil ou aquisição por direito. O contribuinte pode ser o comprador ou beneficiador do imóvel localizado em área urbana ou rural. O ITBI, assim como o IPTU, está ligado à questão imobiliária e apresenta como base de cálculo o valor venal do imóvel gerado a partir da transferência do patrimônio. O imposto, que tem como uma das finalidades o registro de imóveis urbanos e rurais, está relacionado ao fluxo da dinâmica imobiliária dos municípios. Entretanto, no caso do ITBI, o valor é declarado pelo contribuinte, diferentemente do IPTU, em que o valor é calculado e lançado diretamente pelo município competente. Caso o valor declarado não seja aceito pelas autoridades fiscais do município, poderá ser contestado e exigir-se-á como valor venal o valor de mercado.

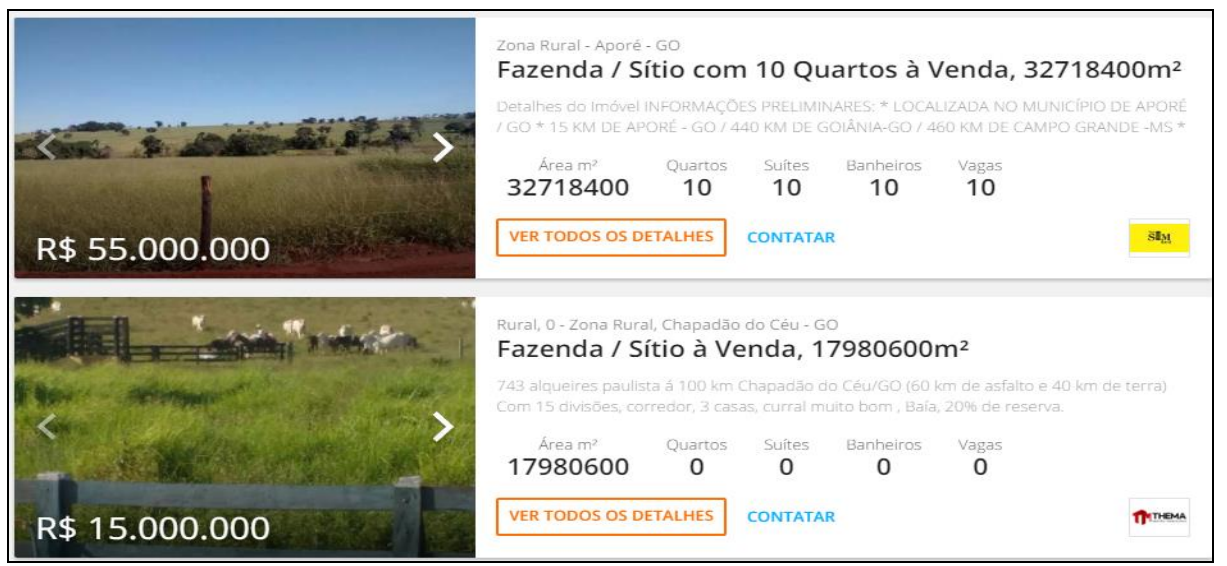

Figura 03: Imóveis à venda nos municípios de Chapadão do Céu e Aporé. Fonte: Classificados Vivareal, 2017. 
Sua alíquota, assim como o IPTU, varia conforme o Código Tributário de cada município ${ }^{4}$. Na MSG os maiores percentuais foram para os municípios de Aporé (757,19\%), Chapadão do Céu $(578,56 \%)$ e Perolândia $(479,30 \%)$. Os percentuais exorbitantes de crescimento desses municípios podem estar aliados ao preço dos imóveis. O ITBI, diferentemente do IPTU ou ITR, não possui incidência em uma zona específica, podendo ser cobrado tanto em imóveis da zona rural quanto da zona urbana. Desse modo, faz sentido que imóveis como os mostrados na Figura 03 ao serem vendidos reverberem em um montante considerável em relação a municípios que têm baixa arrecadação tributária municipal. Caso o imóvel mencionado em Aporé seja vendido, o município arrecada, a uma alíquota exemplar de 3\%, o total bruto de $\mathrm{R} \$$ 1.650.000,00. Esse valor representaria pouco mais de $40 \%$ no município, que no ano de 2015 arrecadou $\mathrm{R} \$ 4.115 .970,31$ em receitas tributárias municipais (TCM-GO, 2015).

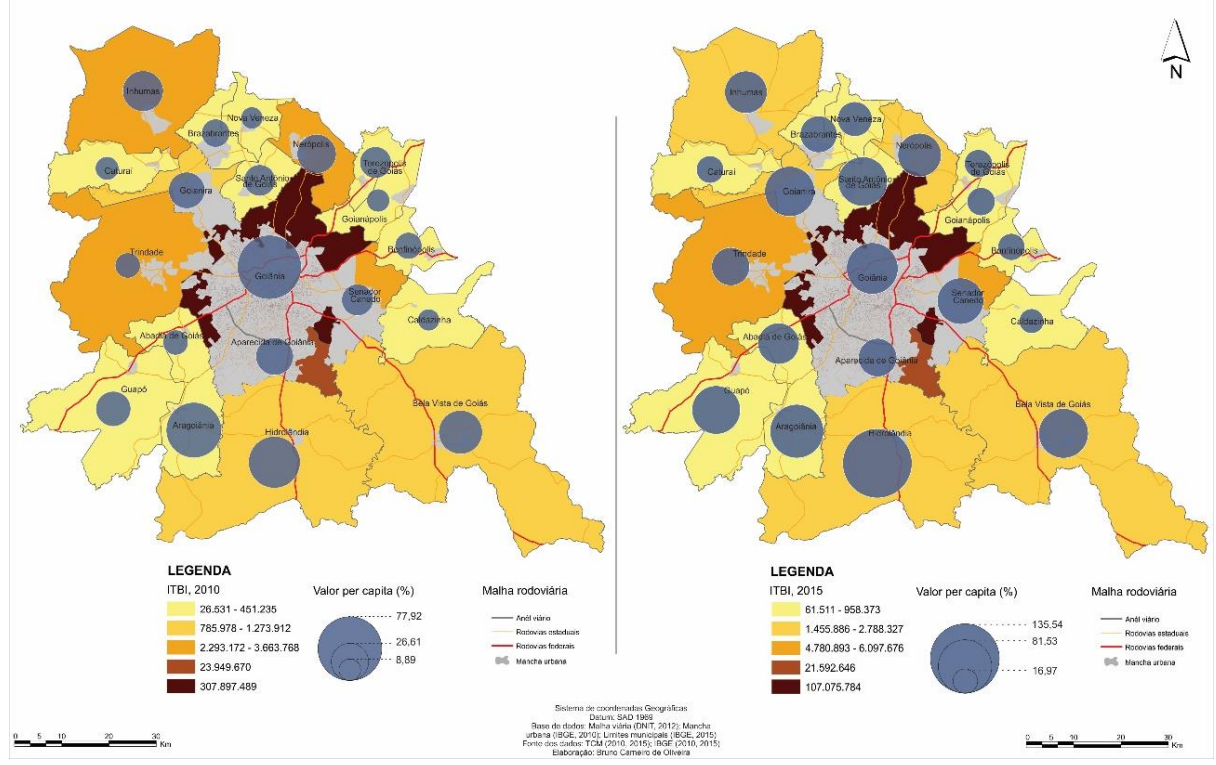

Figura 04: Espacialização do ITBI na RMG em 2010 e 2015. Fonte: TCM $(2010,2015)$; IBGE $(2010,2015)$.

A média de crescimento entre os municípios MSG no período foi de $26,02 \%$ e $112,43 \%$. 8 (oito) municípios figuraram-se abaixo dessa média, com destaque para o decréscimo de arrecadação nos municípios de Portelândia (-51,23\%), Palestina de

\footnotetext{
${ }^{4}$ Em Rio Verde, nas transmissões dentro do Sistema Financeiro de Habitação a alíquota é 3\% sobre o valor não financiado e de $0,5 \%$ para o valor efetivamente financiado. Para as demais transmissões a alíquota é de 3\%. Fonte: Códigos tributários de Goiânia e Rio Verde.
} 
Goiás $(-18,41 \%)$ e Doverlândia $(-11,88 \%)$. Os percentuais de crescimento abaixo da média revelam dificuldades nos instrumentos de arrecadação do tributo ou baixo número ou nenhuma transferência de imóveis no ano de 2015 em relação a 2010. Jataí e Mineiros representaram mais de $30 \%$ do total arrecadado do tributo na MSG no período.

O Imposto Sobre Serviços de Qualquer Natureza (ISSQN) tem como fator gerador a prestação de serviços, seja por empresa ou profissional autônomo, com ou sem estabelecimento fixo. O contribuinte é o prestador do serviço, empresa ou profissional autônomo de atividades estabelecidas pelos códigos tributários. O preço do serviço é a base de cálculo do imposto. As alíquotas variam conforme o tipo de prestação de serviço. O número de domicílios é um fator que guarda relação com o ISSQN, sendo possível perceber que quanto maior a população, maiores são as demandas por domicílios e serviços para atender a população residente de determinado município. Sendo assim, a arrecadação do imposto pela prestação de serviços é relevante para os governos municipais, uma vez que sua destinação deve reverberar para a criação e manutenção de equipamentos de uso coletivo nos municípios. Nos Código Tributário de Rio Verde, por exemplo, é descrito o total de 40 tipos de atividades em que o tributo incide, nos quais as alíquotas variam entre $2 \%$ e $5 \%$.

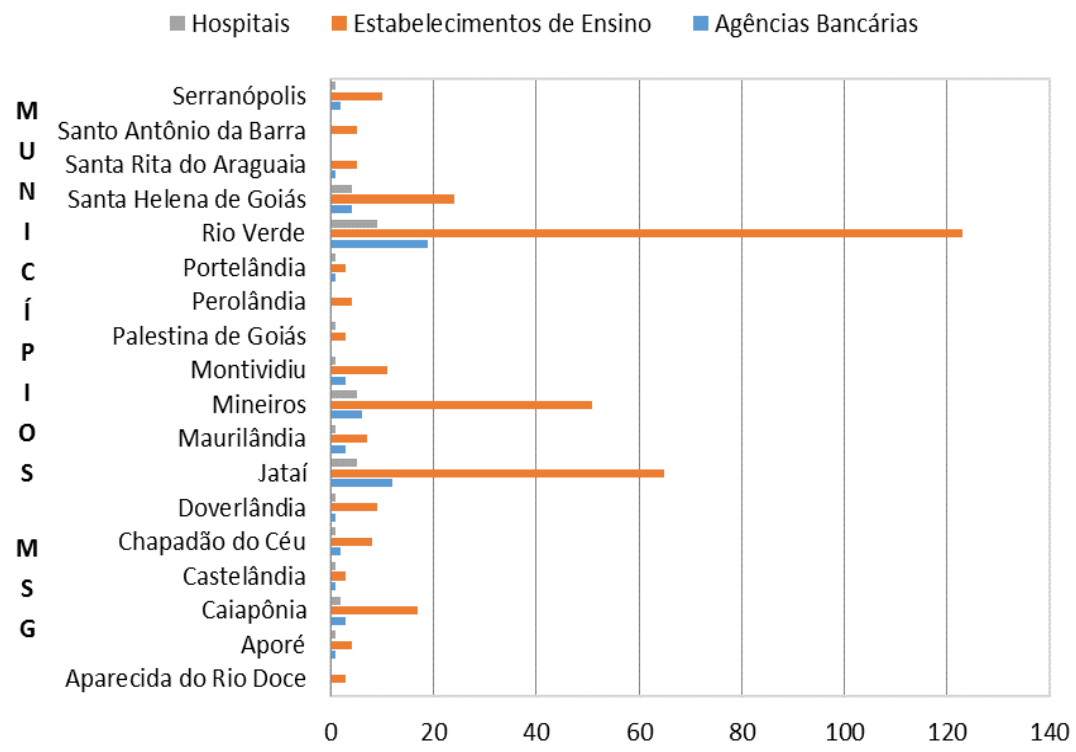

Figura 05: Equipamentos de uso coletivo selecionados nos municípios da RMG e MSG (2015). Fonte: IMB (2015). 
Na MSG observa-se um percentual de crescimento de $103,60 \%$ no período entre 2010 e 2015, resultando em uma arrecadação de $\mathrm{R} \$ 97.296 .221,86$ no último ano desse período, mais que o dobro do arrecadado no ano inicial de análise. Dez dos dezoito municípios da microrregião registraram crescimento de arrecadação acima da média e houve municípios que diminuíram a arrecadação, como Aparecida do Rio Doce (- 9,72\%), Aporé (- 79,99\%) e Montividiu (- 34,70\%). O aumento da receita nessas localidades pode estar ligado tanto ao aumento de equipamentos de serviços quanto à implantação de empresas nesses municípios. Em 2015, as maiores concentrações da receita ocorreram em Rio Verde (47,63\%), Jataí (20,23\%, Mineiros $(12,87 \%)$ e Santa Helena de Goiás (5,67\%), enquanto sete municípios não chegaram a participar com $1 \%$ do total arrecadado na MSG.
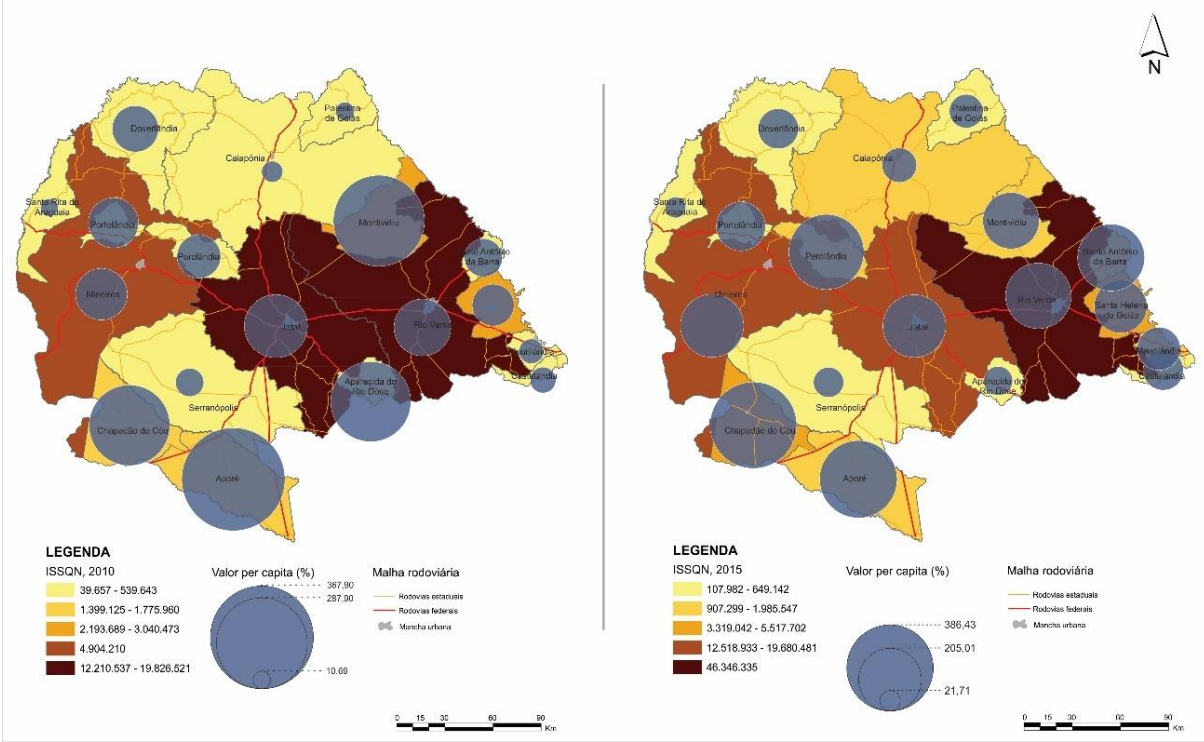

Figura 06: Espacialização do ISSQN na MSG em 2010 e 2015. Fonte: TCM (2010, 2015); IBGE $(2010,2015)$.

Para Arrais et al (2013, p. 94), o ISSQN funciona como "ilustrativo das diferenças em relação aos ambientes metropolitanos", o que, pela presente análise dos dados, pode se estender a regiões como a MSG, por conta da motivação dos usos dos serviços por populações de municípios polarizados por centros regionais. Os percentuais de concentração indicam a polarização de serviços no polo regional. Outro fator que contribui para a maior arrecadação de ISSQN no polo regional são os serviços especializados, como o serviço de oncologia público, na área da saúde, presente em 7 
municípios em todo o estado de Goiás, incluindo-se Rio Verde (GOIÁS, 2016); e o de instituições de ensino superior, concentrados em Rio Verde (9) (MEC, 2017), que possibilitam a mobilidade de pessoas (mesmo na ausência de sistema público de transporte coletivo) e ocasionam o consumo e a prestação de serviços nessas localidades.

O Imposto Territorial Rural (ITR), ao contrário das receitas analisadas anteriormente, é uma transferência constitucional federal que foi selecionada para o estudo por consideramos que na maior parte dos municípios da MSG o ITR participa de modo semelhante às receitas tributárias de origem municipal e apresentar características ligadas à estrutura fundiária dos municípios, tendo como fator gerador do tributo a propriedade territorial rural. É presente no cenário das finanças brasileiras desde a Constituição Federal de 1891 e, desde então, e por diferentes razões, migrou-se entre as competências estadual e municipal. Seu fator gerador é a propriedade territorial rural e atua como instrumento para as políticas agrárias.

Pode ser parcial ou inteiramente destinado aos municípios, caso haja a pactuação de convênio. Sua arrecadação é mínima quando comparada a outras receitas, o que, conforme Lopes Filho (2015), é resultado de "pouco apego" do governo federal à renda gerada, que chega a percentuais de até $50 \%$ a serem repassados ao município, além das baixas alíquotas aplicadas nas propriedades. A pactuação de convênio entre governo federal e município possibilita que o último fique com o total arrecadado. Diante desse contexto, e, portanto, é um dos tributos selecionados para o presente estudo.

As alíquotas para o imposto, baseadas na Lei no 9.393 de 19 de dezembro de 1996, presentes na Tabela 05, dão sinais de como o tributo pode contribuir como instrumento para as políticas agrárias quando aplicado sobre terras não produtivas: quanto maior a área do imóvel rural e menor o seu grau de utilização, maior será a alíquota sobre o valor fundiário. Desse modo, por exemplo, o proprietário de uma fazenda com valor venal de $\mathrm{R} \$ 1.500 .000,00$ de 750 hectares, que possui 425 hectares de área plantada de soja e 125 hectares de área de pastagem pagará aproximadamente $\mathrm{R} \$ 12.650,00 \mathrm{em}$ ITR.

Pode ser parcial (50\%) ou inteiramente destinado aos municípios, caso haja a pactuação de convênio. Os convênios no âmbito do ITR possuem amparo legal na Lei $n^{\circ} 11.250$, de 27 de dezembro de 2005, que possibilitam "atribuições de fiscalização, inclusive a de lançamento dos créditos tributários, e de cobrança do Imposto sobre a Propriedade Territorial Rural" (BRASIL, 2005). A partir de 2008, com o Decreto $\mathrm{n}^{\mathrm{o}}$ 6.433, de 15 de abril de 2008, houve nova resolução relacionada ao convênio, em que os municípios recebem o total do imposto arrecadado relacionado aos imóveis rurais (BRASIL, 2008). Em Goiás, 195 dos 246 municípios atualmente possuem adesão ao convênio. Palestina de Goiás é o único município na MSG que não aderiu ao convênio. O motivo da não adesão pode estar ligado a não oferta de estrutura para a fiscalização e 
arrecadação do imposto e à ausência de equipe capacitada para a realização do trabalho, conforme ocorreu com alguns municípios do estado de Mato Grosso (Agência RD NEWS, 2013).

Tabela 05: Alíquotas para cálculo do ITR conforme o Art. 11 da Lei no 9.393, de 19 de dezembro de 1996.

\begin{tabular}{l|c|c|c|c|c}
\hline \multirow{2}{*}{$\begin{array}{c}\text { Área total do imóvel (em } \\
\text { hectares) }\end{array}$} & \multicolumn{5}{|c}{ Grau de utilização (em \% da área) } \\
\cline { 2 - 6 } & $\begin{array}{c}\text { Maior que } \\
80\end{array}$ & $\begin{array}{c}\text { Maior que 65 até } \\
80\end{array}$ & $\begin{array}{c}\text { Maior que 50 até } \\
65\end{array}$ & $\begin{array}{c}\text { Maior que 30 até } \\
50\end{array}$ & $\begin{array}{c}\text { Até } \\
30\end{array}$ \\
\hline Até 50 & 0,03 & 0,20 & 0,40 & 0,70 & 1,00 \\
\hline Maior que 50 até 200 & 0,07 & 0,40 & 0,80 & 1,40 & 2,00 \\
\hline Maior que 200 até 500 & 0,10 & 0,60 & 1,30 & 2,30 & 3,30 \\
\hline Maior que 500 até 1.000 & 0,15 & 0,85 & 1,90 & 3,30 & 4,70 \\
\hline Maior que 1.000 até 5.000 & 0,30 & 1,60 & 3,40 & 6,00 & 8,60 \\
\hline Acima de 5.000 & 0,45 & 3,00 & 6,40 & 12,00 & 20,00 \\
\hline
\end{tabular}

Fonte: Brasil (1996).

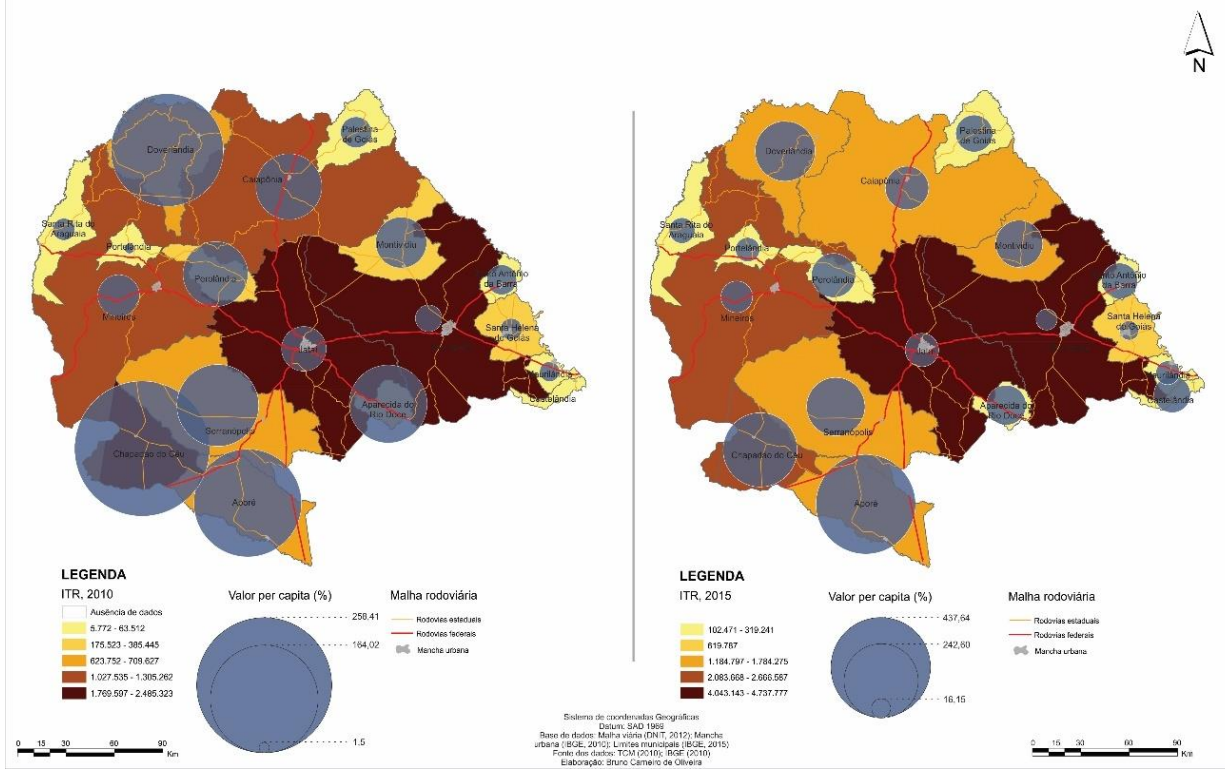

Figura 07: Espacialização do ITR na MSG em 2010 e 2015.

Fonte: TCM (2010, 2015); IBGE (2010, 2015). 
Jataí (21,00\%), Chapadão do Céu (17,23\%) e Rio Verde (14,95\%) foram os três municípios que apresentaram maior arrecadação na MSG. Os dados revelam uma dinâmica fundiária bastante diferenciada entre os ambientes de estudo. Baseado na Tabela 06, nota-se que os municípios da MSG possuem uma alta arrecadação ligada à alta produtividade agropecuária e à área territorial dos municípios, que possibilita a existência do maior número de propriedades rurais.

Tabela 06: Representação (\%) das receitas tributárias selecionadas em relação às receitas públicas municipais totais na MSG no ano de 2015.

\begin{tabular}{c|c|c|c|c|c|c|c|c}
\hline Municípios & IPTU\% & \multicolumn{1}{c}{ ISSQN\% } & \multicolumn{1}{c}{ ITBI\% } & \multicolumn{1}{c}{ ITR\% } & \multicolumn{1}{c}{ ICMS\% } & \multicolumn{1}{c}{ FPM\% } & RPM* total \\
\hline Aparecida do Rio Doce & 0,54 & 1,10 & 1,52 & 1,78 & 36,88 & 55,79 & $9.801 .314,40$ \\
\hline Aporé & 0,24 & 5,55 & 9,65 & 7,84 & 33,57 & 24,03 & $22.757 .990,35$ \\
\hline Caiapônia & 0,75 & 2,89 & 4,76 & 3,93 & 41,20 & 28,58 & $38.266 .657,03$ \\
\hline Castelândia & 0,73 & 3,27 & 1,50 & 2,32 & 31,54 & 58,97 & $9.272 .502,87$ \\
\hline Chapadão do Céu & 2,67 & 7,95 & 2,55 & 4,99 & 66,26 & 13,10 & $41.751 .493,93$ \\
\hline Doverlândia & 0,60 & 4,49 & 2,61 & 8,60 & 7,18 & 37,79 & $14.470 .942,11$ \\
\hline Jataín & 6,16 & 9,69 & 3,96 & 2,33 & 44,45 & 13,46 & $203.095 .081,61$ \\
\hline Maurilândia & 0,00 & 7,73 & 0,00 & 1,99 & 39,39 & 45,37 & $16.070 .401,37$ \\
\hline Mineiros & 5,14 & 12,17 & 4,31 & 2,59 & 46,15 & 19,49 & $102.858 .170,31$ \\
\hline Montividiu & 1,56 & 5,69 & 1,70 & 3,39 & 67,54 & 20,88 & $34.920 .424,14$ \\
\hline Palestina de Goiás & 0,24 & 1,90 & 1,64 & 1,96 & 34,13 & 51,01 & $10.718 .304,66$ \\
\hline Perolândia & 0,22 & 4,87 & 0,84 & 1,43 & 55,83 & 29,32 & $18.648 .388,29$ \\
\hline Portelândia & 0,41 & 3,50 & 1,38 & 0,72 & 54,13 & 38,30 & $14.274 .734,30$ \\
\hline Rio Verde & 5,93 & 12,88 & 4,09 & 1,12 & 48,73 & 14,46 & $359.878 .191,18$ \\
\hline Santa Helena de Goiás & 1,23 & 9,95 & 5,05 & 1,12 & 42,12 & 29,57 & $55.478 .680,75$ \\
\hline Santa Rita do Araguaia & 1,89 & 1,52 & 1,88 & 2,02 & 32,14 & 48,26 & $11.329 .743,62$ \\
\hline Santo Antônio da Barra & 0,03 & 7,99 & 3,08 & 1,94 & 45,69 & 39,91 & $13.701 .208,68$ \\
\hline Serranópolis & 6,22 & 1,84 & 5,10 & 5,96 & 45,84 & 26,70 & $20.476 .949,11$ \\
\hline MSG & 4,38 & 9,75 & 3,86 & 2,29 & 46,72 & 20,19 & $997.771 .178,71$ \\
\hline
\end{tabular}

*Receitas Públicas Municipais Totais. Fonte: TCM-GO (2015); Tesouro Nacional (2015); SEFAZ-GO (2015).

A Tabela 06 mostra a representação das receitas públicas tributárias e transferências constitucionais selecionadas em relação ao total arrecadado em cada município da MSG. Com relação ao custeio total, nota-se que o FPM se configura como a segunda maior fonte representativa de recursos financeiros, participando em mais de $40 \%$ da arrecadação total de 5 municípios, em que 4 desses possuem população menor que 10.000 habitantes. Chapadão do Céu, Jataí e Rio Verde foram os municípios que tiveram a menor participação da transferência federal em sua arrecadação total. $\mathrm{O}$ ICMS na MSG é um recurso decisivo para o custeio da maior parte de seus municípios. É a fonte de recursos mais representativa para 12 dos municípios e, com exceção de Doverlândia, compõe mais $30 \%$ do orçamento de cada município.

O IPTU e o ITBI apresentam relevância somente nos municípios mais populosos, o que pode se dever a uma espécie de "distanciamento" entre gestor e contribuinte. As situações relatadas em Leal (2012) perpetuam-se entre os municípios e a possibilidade de eleição ou reeleição de determinado candidato a prefeito (muitas das 
vezes, de determinado grupo ou determinada família, ou mesmo ambos) podem levar a um prejuízo para o município a longo prazo. O ITR insere-se em uma lógica parecida. Em municípios com alta produtividade agropecuária, como os da MSG, a arrecadação poderia ser maior que a conferida para o ano de 2015, principalmente quando levado em conta a área territorial e o número de propriedades rurais. $\mathrm{Na}$ verdade, parece não haver interesse real na cobrança desse imposto, tanto que o governo federal possui pouco apego com o recurso pelo modo como é arrecadado e repassado (50\% união/50\% município) e pelos convênios que cedem 100\% ao município.

Por fim, podemos dizer que algumas das dificuldades de arrecadação das receitas municipais e dependência majoritária de transferências federais, estaduais e fundos se dá: 1) por conta da concentração de equipamentos de uso comum e consumo nos polos dos ambientes em estudo, que desfavorece a arrecadação de ISSQN; 2) pela possível omissão da cobrança de tributos de origem municipal por parte dos gestores de municípios de menores população para continuidade de "bom relacionamento" com a população local; 3) porque é possível que alguns gestores não tenham interesse ou vontade política de aprimorar os meios de arrecadação municipal com a capacitação de pessoas.

Para cada tributo, podemos pontuar algumas estratégias que podem contribuir para o respectivo aumento de arrecadação, sendo:

1) IPTU: progressividade do tributo no tempo, aliada à atualização periódica da alíquota por zona, seja aplicada em maior escala nos municípios, que poderia contribuir para o arrefecimento da especulação imobiliária em larga escala, gerando recursos alocáveis para a infraestrutura e regularização fundiária de áreas segregadas, possibilitando a não formação de vazios urbanos (SOUZA, 2003);

2) ITBI: aumento da fiscalização no que se refere à compra e venda de imóveis nos municípios e à possibilidade de parcelamento do valor da transferência imobiliária, que permitirá a maior regularização dos imóveis.

3) ISSQN: aplicação de meios que motivem o contribuinte a realizar o pagamento do ISSQN, como premiações pelo montante de notas fiscais, e parceria com instituições financeiras no processo de arrecadação, com a inserção de novas formas de pagamento, como débito em conta bancária, objetivando o aumento das opções das formas de pagamento para o contribuinte, além do desafio em descentralizar serviços para o aumento da arrecadação de ISSQN nos municípios periféricos dos ambientes selecionados;

4) ITR: a proposta feita por Patrus Ananias, em 2015, visava ter o INCRA como fiscal das informações prestadas pelos proprietários rurais no ato do pagamento do tributo. O procedimento seria feito com auxílio de sistema georreferenciado de satélite para checagem das informações sobre valor da terra nua e grau de utilização da terra. A previsão com o projeto era de que a arrecadação saltasse de 850 milhões, no ano de 2014, para 8 bilhões a partir da implementação (O GLOBO, 2015). A proposta é 
interessante, porém, com a vigente exclusão do Ministério do Desenvolvimento Agrário, é possível que a proposta tenha sido até mesmo arquivada.

\section{Considerações Finais}

A dependência das transferências nem sempre é uma saída para o custeio dos municípios, caso consideremos o ICMS, por exemplo, pois o município deve se tornar um ganhador diante das guerras fiscais entre os municípios e regiões. Aos gestores municipais, caberá tornar atrativo o município para que empresas se instalem, possivelmente com a adoção de incentivos como a isenção de IPTU, por exemplo, ou do apoio de corporações a candidatos. É assim que a relação global entre arrecadação tributária e política ganha sentido quando correlacionado a um contexto espacial como o do agronegócio na MSG.

Para todos os tributos é importante que os municípios realizem a tentativa de inovação administrativa, realizando a aquisição de softwares que possibilitem atualização de bancos de dados e cadastro e, fundamentalmente, a capacitação de pessoas para exercer a fiscalização tributária. Para a recuperação da dívida ativa, sugere-se aos municípios o aumento do prazo para parcelamento dos débitos fiscais, renegociação e aplicação de penalidades e infrações, como as sugeridas nos Códigos Tributários. A capacitação de pessoas, melhoramento tecnológico institucional e meios dispostos por parte da prefeitura, renegociação de dívidas oriundas de atraso ou não pagamento dos tributos, parecem ser uma forma para se arrecadar mais com menor dependência de transferências de outras escalas de poder.

A Constituição Federal de 1988 mesmo positiva no que se refere à forma de distribuição das atribuições e meio de conferir maior grau de autonomia aos municípios, deve ter seu debate aprimorado no campo das finanças públicas, das práticas de gestão municipal e das relações intergovernamentais, pois é a partir dela que se avançaremos para a cidadania proposta por Santos Filho (1997), para quem deve ser compreendida além do poder de falar coletivamente e privilegiar o acesso aos serviços básicos de saúde, educação e saneamento. Cabe aos gestores as tentativas de promoção de desenvolvimento por outros meios, como no exemplo dos consórcios públicos intermunicipais. É nesse contexto que as finanças devem ser discutidas na formação social e econômica e que podem possibilitar um diálogo mais sério relativo ao papel, situação e custeio dos municípios no Brasil a exemplo do analisado na MSG.

\section{Referências}

AGÊNCIA RD NEWS. Notícia: 39 municípios de Mato Grosso não aderem a municipalização do ITR. Disponível em: <http://www.rdnews.com.br/variedades/39municipios-de-mato-grosso-nao-aderem-a-municipalizacao-do-itr/41016>. Acesso em: 10 fev. 2017. 
APARECIDA DO RIO DOCE. Código Tributário de Aparecida do Rio Doce. Disponível

em:<http://www.nucleogov.com.br/aparecidadoriodoce/anexos/leis/lei_201604141409 15.pdf>. Acesso em: 05 fev. 2017.

APARECIDA DO RIO DOCE. Lei Complementar no 002/1993 que institui o Código Tributário do Município de Aparecida do Rio Doce, Estado de Goiás, e dá outras providências. Disponível

em:<http://www.nucleogov.com.br/aparecidadoriodoce/leis/>. Acesso em: 05 abr. 2017.

ARRAIS, T. A. As receitas públicas municipais e a funcionalidade da integração espacial em ambientes metropolitanos. Sociedade \& Natureza, v. 26, n. 2, p. 201-220, 2014.

BORGES, E. B. Incentivos fiscais e desenvolvimento socioeconômico de Goiás : análise de impactos dos Programas Fomentar e Produzir (1995-2011). Tese (Doutorado em Políticas Públicas, Estratégias e Desenvolvimento) - Universidade Federal do Rio de Janeiro, Instituto de Economia, Programa de Pós-Graduação em Políticas Públicas, Estratégias e Desenvolvimento, 2014.

BORGES, R. E. No meio da soja, o brilho dos telhados: a implantação da Perdigão em Rio Verde (GO), transformações e impactos socioeconômicos e espaciais. Tese (Doutorado em Geografia) - Universidade Estadual Paulista, Instituto de Geociências e Ciências Exatas, 2006

BRASIL. Constituição Federal de 1988. Brasília, 1988. Disponível em: <http://www.planalto.gov.br/ccivil_03/constituicao/constituicaocompilado.htm〉. Acesso em: 02/02/2016.

Lei $\mathrm{n}^{\circ}$ 5.172, de 25 de outubro de 1966. Dispõe sobre o Sistema Tributário Nacional e institui normas gerais de direito tributário aplicáveis à União, Estados e Municípios. Diário Oficial da União, 27 de outubro de 1966. Disponível em: <http://www.planalto.gov.br/ccivil_03/leis/L5172.htm>. Acesso em: 15 jul. 2016.

. Lei no 9.393 de 19 de dezembro de 1996. Dispõe sobre o Imposto sobre a Propriedade Territorial Rural - ITR, sobre pagamento da dívida representada por Títulos da Dívida Agrária e dá outras providências. Disponível em: <http://www.planalto.gov.br/ccivil_03/leis/L9393.htm>. Acesso em: 02 fev. 2017.

. Lei no 4.320, de 17 de março de 1964. Estatui Normas Gerais de Direito Financeiro para elaboração e contrôle dos orçamentos e balanços da União, dos Estados, dos Municípios e do Distrito Federal. Brasília, 4 mai. 1964. Disponível em: <http://www.planalto.gov.br/ccivil_03/leis/L4320.htm〉. Acesso em: 15 jul. 2016.

BRASIL (Controladoria Geral da União). Manual para os agentes municipais. Brasília: Secretaria Federal de Controle Interno, 2005. Disponível em: <http://www.cgu.gov.br/Publicacoes/auditoria-efiscalizacao/arquivos/cartilhagestaorecursosfederais.pdf>. Acesso em: Acesso em: 15 jul. 2016. 
ELIAS, D. Agronegócio e novas regionalizações no Brasil. Revista Brasileira de Estudos Urbanos e Regionais, v. 13, n. 2, p. 153-167, 2012.

ELIAS, D. Globalização e fragmentação do espaço agrícola do Brasil. Scripta Nova. Revista electrónica de geografía y ciencias sociales. Barcelona: Universidad de Barcelona, 1 de agosto de 2006, vol. X, núm. 218 (03).

FERREIRA, D. F.; FERNANDES FILHO, J. F. Análise das transformações recentes na atividade agrícola da Região Sudoeste de Goiás (1970-1995-6). In.: PEREIRA, S.L.; XAVIER, C.L. (Orgs.) O agronegócio nas terras de Goiás. Uberlândia: Edufu, 2003.

GOIÁS (Secretaria de Saúde). Mapa da Saúde de Goiás. Serviço de oncologia disponibilidade. Disponível

em: <http://www.saude.go.gov.br/public/media/mapa_saude/capacidade_instalada/Servico_ Saude/Z_Dispon_Oncologia/gc5200mrl.htm>. Acesso em: 02 fev. 2017.

HAESBAERT, R. Regional-global: dilemas da região e da regionalização na geografia contemporânea. Rio de Janeiro: Bertrand Brasil, 2014.

IBGE (Instituto Brasileiro de Geografia e Estatística). Estimativas da população brasileira. 2015.

. Censo Demográfico: 2010. Rio de Janeiro, 2010.

. Censo Demográfico: 2010. Rio de Janeiro, 2010.

IMB (Instituto Mauro Borges de Economia e Estatística). Dados sobre infraestrutura, produção agropecuária e serviços públicos na Microrregião Sudoeste de Goiás.

Goiânia, 2017.

INCRA. Sistema Nacional de Cadastro Rural Índices Básicos de 2013. Disponível em: <http://www.incra.gov.br/sites/default/files/uploads/estrutura-fundiaria/regularizacaofundiaria/indices-cadastrais/indices_basicos_2013_por_municipio.pdf >. Acesso em: 15 fev. 2017.

JATAÍ. Lei Complementar $n^{\circ} 1445$ de 27 de dezembro de 1990 que institui o Código Tributário do município de Jataí. Disponível em:

<http://www.jatai.go.gov.br/index.php?option=com_docman\&task=doc_view\&gid=38 96\&tmpl=component\&format=raw\&Itemid=220>. Acesso em: 10 abr. 2017.

LEAL, V. N. Coronelismo, enxada e voto. Editora Companhia das Letras, 2012.

LOPES FILHO, J. M. Imposto Predial e Territorial Urbano (IPTU) e Imposto Territorial Rural (ITR). São Paulo: Atlas, 2015.

MEC (Ministério da Educação). Cadastro e-MEC de Instituições e Cursos de Educação Superior. Instituições de Educação Superior e Cursos Cadastrados. Disponível em: <http://emec.mec.gov.br/>. Acesso em: 02 fev. 2016.

MENDES, J. T. G.; PADILHA JÚNIOR, J. B. P. Agronegócio: uma abordagem econômica. Pearson Prentice Hall, 2007. 
MONTIVIDIU. Código Tributário de Montividiu. Disponível em: <http://www.camaramontividiu.com.br/wp-content/uploads/2015/06/C\%C3\%B3digoTributario.pdf>. Acesso em: 05 fev. 2017.

O GLOBO. Notícia: Governo quer mais controle de Imposto da Propriedade Rural. Disponível em: <http://oglobo.globo.com/brasil/governo-quer-mais-controle-deimposto-da-propriedade-rural-17637148>.

RIBEIRO, A. C. T. Regionalização: fato e ferramenta. In: Limonad, E. et al. (Org.). Brasil Século XXI: por uma nova regionalização? São Paulo: Max Limonad, 2004.

RIO VERDE. Código Tributário de Rio Verde. Disponível em: <http://www.rioverdegoias.com.br/fazenda/arquivos/download-item/downs-47-0.pdf>. Acesso em: 05 fev. 2017.

SANTOS FILHO, M. As relações fiscais e financeiras entre Município, Estado e a União no Brasil atual. In: SANTOS FILHO (Org.): Finanças Locais e Regionais. Bahia: Hucitec, 1996.

SANTOS, M. Técnica, espaço, tempo. São Paulo: Hucitec, v. 3, 1994.

SANTOS, M.; SILVEIRA, M. L. O Brasil: território e sociedade no início do século XXI. Rio de Janeiro: Record, 2008.

SOUZA, M. L. Mudar a Cidade: uma Introdução Crítica ao Planejamento e à Gestão Urbanos. 2a . Ed., Rio de Janeiro: Bertrand Brasil, 2003.

TCM-GO (Tribunal de Contas dos Municípios do Estado de Goiás). Portal do Cidadão - receitas do executivo municipal. Goiás, 2015.

ÚNICA (União das Indústrias da Cana-de-Açúcar). Grupos associados por estadoGoiás, 2017. Disponível em:

<http://www.unica.com.br/empresas/acao=filtrar\&id=\&uf=GO>.

\footnotetext{
Bruno Carneiro Oliveira

Graduado em Geografia pela Universidade Federal de Goiás, com período sanduíche na University of Massachusetts Amherst, e Mestrado em Geografia pela Universidade Federal de Goiás.

IESA, Campus Samambaia, Conjunto Itatiaia, Caixa Postal 131, Cep: 74001-970

- Goiânia/GO.

E-mail: lucasgvb1991@hotmail.com
} 